\title{
Biophysical Reviews enters the online world, provides a focus on biophysics in Asia
}

\author{
Damien Hall ${ }^{1,2}$ (D) \\ Received: 28 April 2019 / Accepted: 29 April 2019 / Published online: 18 May 2019 \\ (C) Crown 2019
}

This Special Issue of Biophysical Reviews is dedicated to the joint meeting of the Asian Biophysics Association (ABA) and the Australian Society for Biophysics (ASB), held in Melbourne in December of 2018. The ABA is an interesting beast. It is a loose confederacy of national societies located in the greater Asia region. Presently, the ABA is composed of the Biophysical Societies of China, India, Japan, Hong Kong, Taiwan, Korea, and Australia. Due to growing investment in basic science throughout the Asia region, it could be argued that the ABA is one of the most dynamic focal points for the presentation and discussion of biophysics in the world today. This Special Issue was curated and edited by six Guest Editors, Prof. Kuniaki Nagayama, Prof. Hiroyuki Noji, Prof. Raymond Norton, Prof. Kyeong Kyu Kim, Assoc. Prof. Till Böcking, and Dr. Andrew Battle. I would like to congratulate these Editors for their remarkable efforts in producing this very interesting snapshot of the ABA/ASB event. By combining commentaries from the individual societies, together with series of review articles on topics presented at the meeting, they have managed to provide a flavor of the meeting, as well as communicating very well the efforts of the individual national biophysical societies in their attempts to build local collaboration networks amongst their Asian neighbors. The following Editorial (Battle et al. 2019) provides greater details on the particulars of this issue and I recommend it to you.

This editorial for volume 11, issue 3 of Biophysical Reviews provides a brief summary of contents, along with a discussion of some matters affecting, and of interest to, readers of the journal

Damien Hall

damien.hall@protein.osaka-u.ac.jp; damien.hall@nih.gov; damienhall30@gmail.com

1 Laboratory of Biochemistry and Genetics, NIDDK, NIH, Bld. 8, Bethesda, MD 20892-0830, USA

2 Institute for Protein Research, Osaka University, 3-1-Yamada-oka, Suita, Osaka 565-0871, Japan
Starting this year, Biophysical Reviews has taken the plunge and entered the social media world. From a personal perspective, I am not entirely certain whether social media is necessarily a good thing for science (at least not in the sense of science being a pastime based on introspective quiet contemplation). However, undoubtedly, the nature of communication in science, and indeed the society in which science is conducted, is rapidly changing. Whether this is something to be embraced, or something to be lamented, we shall see. As a journal, we have decided to adopt the former, more hopeful perspective, and in this spirit have launched a Biophysical Reviews Twitter ${ }^{\mathrm{TM}}$ account and a Biophysical Reviews YouTube $^{\mathrm{TM}}$ channel to further promote the work published within, and the activities carried out by, the journal. The online address of these two social media accounts can be found here.

YouTube: https://www.youtube.com/channel/UCzG 5MWmnrB2UBibtxs2DuA

Twitter: @BiophysicalRev1

As they say, if you like the contents please click the subscribe link and smash like below.

On a different matter, Biophysical Reviews would like to note some changes to the Editorial Board. Due to his becoming the new Chief Editor Elect of the Japanese Biophysical Society's flagship publication, "Biophysics and Physicobiology," Prof. Haruki Nakamura has stood down from his Executive Editor role and now rejoins the Editorial Board as an appointed Member. Three new Executive Editors, Prof. Rosangela Itri (Brazil), Assoc. Prof. Joshua Ho (Hong Kong), and Prof. Kuniaki Nagayama (Japan), have agreed to join with the existing Executive Editors, Prof. Wilma Olson (USA) and Prof. N.R. Jagannathan (India), to help continue steering the journal's course in the right direction. Biophysical Reviews is lucky to have these new Editors and will undoubtedly benefit from their input. Furthermore, six new Members have been appointed to the Editorial Board - these new Members are Prof. Jeremy Tame (Japan), Prof. Karthe Ponnuraj (India), Prof. Junichi Higo (Japan), Assoc. Prof. Keith Shearwin (Australia), Assoc. Prof. Akira Kinjo (Brunei), and Dr. James McNamara (USA). On 
behalf of Biophysical Reviews, I would like to thank these new Board Members for agreeing to spend their free time providing a service to the biophysics community.

On a sadder note, we mark the recent death of Prof. Fumio Oosawa of Japan. Prof. Oosawa was one of the most important biophysical scientists of the last 100 years. His work, spanning areas as diverse as the entropic depletion force (Asakura and Oosawa 1954), protein polymerization (Oosawa and Asakura 1975), and poly-electrolyte theory (Oosawa 1971), mark him as a true intellectual giant. His effect on the development of biophysical science in Japan was indeed formative. As a longterm scientific hero of mine, I was very fortunate to be able to meet with Prof. Oosawa at his retirement home in 2012. Together with a few of his former colleagues in attendance, I presented a talk about my work in his room, with the slides projected onto the wall - a truly unforgettable experience and one that I will always treasure. To better inform the readers of Biophysical Reviews about this important scientist, the journal has commissioned a Letter from his close acquaintances, describing aspects of his life and works. This Letter will be published in a forthcoming issue.

In the last issue, Prof. Cristobal dos Remedios announced the sad news of the death of Biophysical Reviews' Editorial Board Member, Prof. Michèle Auger. A moving obituary describing Michèle's life can be found online at the IUPAB Newsletter site (IUPAB 2019). As a mark of our fondness for Michèle, the Biophysical Review's Board, together with the kind support of Springer-Nature Corporation, would like to announce a perpetual memorial award in honor of Michèle's life and service. The, 'Michèle Auger Award for Young Scientists' Independent Research', will be granted each year to a single candidate performing biophysical research, who at the time of application is under 40 years of age. The award will consist of a plaque and a free personal subscription to the journal along with an invitation to submit a single author Review article to Biophysical Reviews. The published Review will carry a short foreword about the life of Prof. Michèle Auger, along with her work associated with teaching and training the next generation of biophysical scientists. Nominations can be made in the form of a candidate's one page curriculum vitae, along with five original manuscripts, to be submitted by email to either the Chief Editor, or any one of the Biophysical Review's Executive Editors, prior to October 31. Judging will be carried out by a special committee assembled from the Editorial Board, with this assembly taking place after the submission deadline. The winner will be announced in December, with the winner's single author Review to be published in the following year.
In closing, I would like to say that as Biophysical Reviews continues to go from strength to strength, we look for new ways to improve the publishing experience for our authors. Mindful of the IUPAB mission to assist biophysicists located throughout the world with the publication and dissemination of their work, we are continuing to develop our association with different national (and international) societies. Through the production of feature issues (such as the present issue on the joint ABA/ASB Meeting), Biophysical Reviews has found a new and interesting way to present topical biophysical research that is also able to highlight the human and societal dimensions in which these research activities are brought to fruition. If you are interested in doing the same for your Society, then please contact either the Chief Editor, or your local Biophysical Reviews Editorial Board Member, to begin initial inquiries.

Acknowledgments I thank Prof. Wilma Olsen, Assoc. Prof. Joshua Ho, Dr. Reed Wickner, Prof. Junichi Takagi and Dr. Herman Edskes for helpful comments made on an initial draft of this article. I would like to acknowledge the Institute for Protein Research at Osaka University for continuing remarkable support. I gratefully acknowledge the US Government for funds provided in the form of an ORISE Established Scientist Position carried out at the NIDDK. This research was supported in part by an appointment to the National Library of Medicine (NLM) Research Participation Program. This program is administered by the Oak Ridge Institute for Science and Education through an interagency agreement between the U.S. Department of Energy (DOE) and the National Library of Medicine (NLM). ORISE is managed by ORAU under DOE contract number DE-SC0014664. All opinions expressed in this paper are the author's and do not necessarily reflect the policies and views of NLM, DOE, or ORAU/ORISE.

\section{References}

Asakura S, Oosawa F (1954) On interaction between two bodies immersed in a solution of macromolecules. J Chem Phys 22(7):1255

Battle A, Böcking T, Norton R, Kim KK, Noji H, Nagayama K (2019) Special issue of Biophysical Reviews dedicated to the joint 10th Asian Biophysics Association Symposium and 42nd Australian Society for Biophysics Meeting, Melbourne, Australia, December 2-6, 2018. Biophys Rev 11(3)

IUPAB (2019) Newsletter, issue 70 (February). http://iupab.org/2018/11/ 06/obituary-michele-auger-former-iupab-councilor/

Oosawa F (1971) Polyelectrolytes. Academic, New York

Oosawa F, Asakura S (1975) Thermodynamics of the polymerization of protein. Academic, New York

Publisher's note Springer Nature remains neutral with regard to jurisdictional claims in published maps and institutional affiliations. 